\title{
Liquid Formulation of the Postharvest Biocontrol Agent Candida sake CPA-1 in Isotonic Solutions
}

\author{
Maribel Abadias, Josep Usall, Neus Teixidó, and Immaculada Viñas
}

Postharvest Unit, CeRTA, Centre UdL-IRTA, 177 Rovira Roure Avenue, 25198 Lleida, Catalonia, Spain. Accepted for publication 28 October 2002.

\section{ABSTRACT}

Abadias, M., Usall, J., Teixidó, N., and Viñas, I. 2003. Liquid formulation of the postharvest biocontrol agent Candida sake CPA-1 in isotonic solutions. Phytopathology 93:436-442.

Viability of the postharvest biocontrol agent Candida sake CPA-1 stored as liquid formulation was evaluated by studying the effect of growth, preservation medium, and temperature. C. sake was grown in molasses medium with unmodified water activity $\left(\mathrm{a}_{\mathrm{w}}\right)$ and in the same with $\mathrm{a}_{\mathrm{w}}$ modified to 0.98 with the addition of several solutes. Cells were preserved with isotonic solutions of different substances. Efficacy of liquid formulations stored for different periods was tested against infection by Penicillium expansum on apples. The best growth media were the unmodified one and those modified to $0.98 \mathrm{a}_{\mathrm{w}}$ with the addition of glycerol or sorbitol. For all growth media, the best preservation medium was the isotonic solution prepared with trehalose. When the effect of trehalose concentration in the preservation medium was studied, generally, at trehalose concentrations below the isotonic one, $C$. sake viabilities increased with increased trehalose. However, the best results were obtained when cells were preserved with the trehalose solution which was isotonic with cells. After 7 months of storage at $4^{\circ} \mathrm{C}$, cells that were grown in the sorbitol-modified medium and preserved with the isotonic solution of trehalose $(0.96 \mathrm{M})$ maintained their viability and efficacy against $P$. expansum infection of apples.
Biological control of postharvest diseases of fruits has advanced greatly during the past decade. Concerns regarding human health and environmental risks associated with chemical residues in foods have been the main driving force of the search for new and safer control methods (8). Among the proposed alternatives, the use of naturally occurring antagonistic microorganisms has been the most extensively studied. Some of this technology has been patented and commercial products such as Aspire, recently named Decco I-182 (Candida oleophila I-182, Ecogen Corp., Langhorne, PA), Bio-Save 100, 110, and 1000 (Pseudomonas syringae ESC10 and 11, EcoScience Corp., Orlando, FL), and Yield Plus (Cryptococcus albidus, Anchor Bio-Technologies, Cape Town, South Africa) have been registered for commercial use against postharvest decay of citrus and pome fruits.

Recent reports have indicated that Candida sake CPA-1 is an effective biocontrol agent of the major fungal pathogens of pome fruits at a small, semicommercial $(25,26,31)$ and commercial (27) scale. A major obstacle to the commercialization of biocontrol products is the development of a shelf-stable formulated product that retains biocontrol activity similar to that of the fresh cells (16). Drying the product and maintenance in a dry environment or suspension in oil are common approaches that allow microbial agents to be handled in commercial channels of distribution and storage (21). Postharvest biocontrol agents that are now in the market are presented as a wettable powder (Aspire) or as frozen cell concentrated pellets (Bio-Save 100, 110, and 1000). The former can be stored for at least 400 days under refrigeration or for 20 days at room temperature, whereas the Bio-Save series should be stored and distributed under freezer conditions. The feasibility of presenting the biocontrol agent $C$. sake as a solid formulation has been recently studied using freeze-drying as a dehydration method (1). Viability of $C$. sake cells after freeze-

Corresponding author: M. Abadias; E-mail address: isabel.abadias@irta.es

Publication no. P-2003-0210-01R

(c) 2003 The American Phytopathological Society drying was $85 \%$, but the efficacy of the dried product against Penicillium expansum infection of apples was lower than that obtained with fresh cells. Moreover, its viability decreased up to $10 \%$ after 2 months of storage at $4^{\circ} \mathrm{C}$ (1). Liquid formulation of the product could be an alternative to freeze-drying.

There is little published research concerning the impact of growth culture on the viability of a formulated biocontrol agent. Previous studies have demonstrated that growth of $C$. sake in a commercial molasses-based medium or in the same medium with lowered water activity $\left(\mathrm{a}_{\mathrm{w}}=0.98\right)$ showed high viable counts and increased the intracellular concentration of arabitol and glycerol and the water stress resistance of the cells (3). Moreover, the intracellular water potential of cells decreased with lowered $a_{w}$ of the culture medium (2). The objectives of this work were to study (i) the viability of $C$. sake cells grown in different $\mathrm{a}_{\mathrm{w}}$-modified molasses media and preserved in isotonic solutions of several solutes in order to maintain the osmotic equilibrium between the cells and the external medium; (ii) the effect of storage temperature on the viability of isotonic solutions of $C$. sake; (iii) the viability of $C$. sake cells grown in different media and preserved in different trehalose solutions; and (iv) the efficacy of these stored liquid formulations against $P$. expansum infection of $\mathrm{cv}$. Golden Delicious apples.

\section{MATERIALS AND METHODS}

Yeast isolate and pathogen. We used strain CPA-1 of the yeast C. sake (Colección Española de Cultivos Tipo, Spain, CECT10817) obtained from UdL-IRTA, Catalonia, Spain. This strain was isolated from the apple surface and has antagonistic activity against $P$. expansum, Botrytis cinerea, and Rhizopus nigricans in pome fruits (31). Stock cultures were stored at $4^{\circ} \mathrm{C}$ on nutrient yeast dextrose agar slants (NYDA; nutrient broth, $8 \mathrm{~g} \mathrm{liter}^{-1}$; yeast extract, $5 \mathrm{~g} \mathrm{liter}^{-1}$; dextrose, $10 \mathrm{~g} \mathrm{liter}^{-1}$; and agar, $15 \mathrm{~g} \mathrm{liter}^{-1}$ ) and were subcultured on NYDA plates at $25^{\circ} \mathrm{C}$. Isolate CMP-1 of $P$. expansum Link was isolated from a decayed apple that had been in cold storage for several months. This isolate was the most 
aggressive one in our collection and caused the largest lesions on inoculated apples. The fungus was maintained on potato dextrose agar (PDA; $200 \mathrm{ml}$ of extract from boiled potatoes, $20 \mathrm{~g}$ of dextrose, $20 \mathrm{~g}$ of agar, and $800 \mathrm{ml}$ of deionized water) with periodic transfers through apple tissue.

Composition of the growth media and isotonic preservation solutions. Cells were grown in nonmodified and $\mathrm{a}_{\mathrm{w}}$-modified liquid molasses-based media. Nonmodified $\mathrm{a}_{\mathrm{w}}$ medium was used as a control (cane molasses $40 \mathrm{~g} \mathrm{liter}^{-1}$, urea $1.2 \mathrm{~g} \mathrm{liter}^{-1} ; 0.996 \mathrm{a}_{\mathrm{w}}$ ).

Liquid $\mathrm{a}_{\mathrm{w}}$-modified molasses media were prepared at $0.98 \mathrm{a}_{\mathrm{w}}$ with the addition of glycerol $\left(92.0 \mathrm{~g} \mathrm{liter}^{-1}\right)$, glucose $\left(187.3 \mathrm{~g} \mathrm{liter}^{-1}\right)$, $\mathrm{NaCl}$ (35.5 $\left.\mathrm{g} \mathrm{liter}^{-1}\right)$, proline (100 $\left.\mathrm{g} \mathrm{liter}^{-1}\right)$, or sorbitol (198.2 $\mathrm{g}$ liter $\left.{ }^{-1}\right)(2)$.

Low water potential solutions used as preservation media were prepared with arabitol, erythritol, glycerol, glycine, mannitol, proline, sorbitol, and trehalose. These solutes were added to deionized water at the concentration to obtain the same (isotonic) water potential as the cells (Table 1). The water potential of the cells, $\Psi_{c}$, was measured by thermocouple psychrometry with a HR-33T Dew Point Microvoltmeter coupled to a C-52 chamber (Wescor Inc., Logan, UT). The water potential of the liquid preservation media varied with the growth medium and was adjusted to $-0.31,-1.04,-2.30,-2.42,-2.86$, and $-2.97 \mathrm{MPa}$ for the control, glucose-, glycerol-, proline-, $\mathrm{NaCl}-$, and sorbitol- modified media, respectively (2).

Viability of $C$. sake in isotonic liquid formulations. In the first experiment, $200 \mathrm{ml}$ of each of the six studied media in $500-\mathrm{ml}$ conical flasks were inoculated to an initial concentration of $10^{4} \mathrm{CFU} \mathrm{ml} \mathrm{m}^{-1}$ of $C$. sake. Inoculated flasks were incubated at $25^{\circ} \mathrm{C}$ on a shaker at $150 \mathrm{rpm}$ for $48 \mathrm{~h}$. A $10-\mathrm{ml}$ subsample from each medium was distributed in 15-ml sterile centrifuge tubes and centrifuged immediately for $15 \mathrm{~min}$ at $250 \times \mathrm{g}$. Cells were resus- pended in $10 \mathrm{ml}$ of sterile preservation solution prepared as described previously. For each combination of culture medium and preservation solution, the initial concentration of viable cells per milliliter $\left(\mathrm{CFU} \mathrm{ml} \mathrm{m}^{-1}\right.$ ) was determined by plating the serial dilutions on NYDA. Samples were stored at $25^{\circ} \mathrm{C}$ for 10 days and the number of viable cells was determined. Percent viability was calculated by comparing results obtained after the storage period with the initial concentration. There were four replications of each treatment, and the experiment was conducted two times.

In the second experiment, $500 \mathrm{ml}$ of unmodified molasses medium and glycerol- and sorbitol-modified media were prepared in 1-liter conical flasks and were inoculated with a suspension of

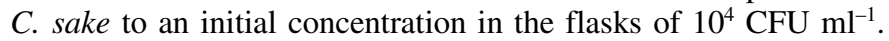
Flasks were incubated at $25^{\circ} \mathrm{C}$ on a shaker at $150 \mathrm{rpm}$ for $48 \mathrm{~h}$. One-hundred-milliliter subsamples of each medium were centrifuged at $8,300 \times g$ for $10 \mathrm{~min}$ at $10^{\circ} \mathrm{C}$. The yeast pellet was resuspended in $80 \mathrm{ml}$ of the isotonic solution tested as a preservation medium, and the initial concentration of viable cells was determined. Four $10-\mathrm{ml}$ subsamples were stored at $4^{\circ} \mathrm{C}$ and an additional four at $25^{\circ} \mathrm{C}$. Furthermore, the effect of the isotonic solutions was compared with both water and $0.05 \mathrm{M}$ potassium phosphate buffer (PB; $\mathrm{pH}$ 6.5). Sampling was done at different periods of time according to the storage temperature. The experiment was conducted two times.

Viability of $C$. sake stored at $4{ }^{\circ} \mathrm{C}$ in solutions with different trehalose concentrations. To study the effect of trehalose on the viability of $C$. sake cells, the organism was grown in nonmodified and glycerol- and sorbitol-modified medium, centrifuged, and resuspended in $\mathrm{PB}$ and $0.03,0.14,0.81$, and $0.96 \mathrm{M}$ trehalose solutions as described previously. Sampling was done monthly.

Efficacy of liquid formulations. The efficacy of all isotonic formulations after 4 months of storage at $4^{\circ} \mathrm{C}$ was tested against $P$.

TABLE 1. Concentration of solutes (mole per liter, M) for liquid preservation media, depending on the solute used to modify the water activity of growth media to $0.98^{\mathrm{z}}$

\begin{tabular}{|c|c|c|c|c|c|c|}
\hline \multirow{2}{*}{$\begin{array}{l}\text { Solute in } \\
\text { preservation medium }\end{array}$} & \multicolumn{6}{|c|}{ Solute in growth medium } \\
\hline & None & Glucose & Glycerol & Proline & $\mathrm{NaCl}$ & Sorbitol \\
\hline Arabitol & 0.17 & 0.48 & 1.04 & 1.07 & 1.20 & 1.25 \\
\hline Erythritol & 0.17 & 0.46 & 1.07 & 1.09 & 1.26 & 1.30 \\
\hline Glycerol & 0.10 & 0.40 & 0.95 & 0.98 & 1.13 & 1.16 \\
\hline Glycine & 0.17 & 0.42 & 0.91 & 0.96 & 1.08 & 1.20 \\
\hline Mannitol & 0.13 & 0.39 & 0.93 & 0.97 & 1.12 & 1.13 \\
\hline Proline & 0.17 & 0.42 & 0.91 & 0.96 & 1.09 & 1.22 \\
\hline Sorbitol & 0.14 & 0.43 & 0.93 & 0.94 & 1.07 & 1.09 \\
\hline Trehalose & 0.14 & 0.36 & 0.81 & 0.84 & 0.93 & 0.96 \\
\hline
\end{tabular}

$\bar{z}$ The molarity of liquid preservation media was prepared in order to obtain solutions with the same water potential as the cells. Water potential of cells was measured as described previously (2).

TABLE 2. Viability (\%) of Candida sake cells grown in unmodified molasses medium (none) and modified to 0.98 water activity with glycerol, sorbitol, proline, glucose, or $\mathrm{NaCl}$ following storage in liquid at $25^{\circ} \mathrm{C}$ for 10 days ${ }^{\mathrm{x}}$

\begin{tabular}{|c|c|c|c|c|c|c|c|}
\hline \multirow{2}{*}{$\begin{array}{l}\text { Solute in } \\
\text { preservation medium }\end{array}$} & \multicolumn{7}{|c|}{ Solute in growth medium } \\
\hline & None & Glycerol & Sorbitol & Proline & Glucose & $\mathrm{NaCl}$ & Mean $^{y}$ \\
\hline Trehalose & $25(3)$ & $21(2)$ & $30(9)$ & $16(2)$ & $11(1)$ & $7(4)$ & $16 \mathrm{a}$ \\
\hline Glycerol & $12(1)$ & $10(1)$ & $7(0)$ & $8(0)$ & $4(0)$ & $10(6)$ & $8 \mathrm{~b}$ \\
\hline Proline & $11(1)$ & $9(1)$ & $12(1)$ & $6(1)$ & $3(1)$ & 2 (1) & $7 \mathrm{bc}$ \\
\hline Mannitol & $10(1)$ & $8(1)$ & $6(1)$ & $6(1)$ & $3(0)$ & $2(1)$ & $6 \mathrm{~cd}$ \\
\hline Sorbitol & $9(1)$ & $9(1)$ & $6(1)$ & $7(1)$ & $3(1)$ & $2(1)$ & $5 \mathrm{~cd}$ \\
\hline Arabitol & $8(1)$ & $8(1)$ & $5(0)$ & $7(1)$ & $3(0)$ & $3(2)$ & $5 \mathrm{~cd}$ \\
\hline Glycine & $8(1)$ & $8(0)$ & $5(0)$ & $8(1)$ & $3(0)$ & $3(1)$ & $5 \mathrm{~cd}$ \\
\hline Erythritol & $7(1)$ & $7(1)$ & $6(1)$ & $5(1)$ & $3(1)$ & $2(1)$ & $5 \mathrm{~cd}$ \\
\hline Meanz & $11 \mathrm{v}$ & $10 \mathrm{vw}$ & 8 wx & $7 x$ & $4 y$ & $3 z$ & \\
\hline
\end{tabular}

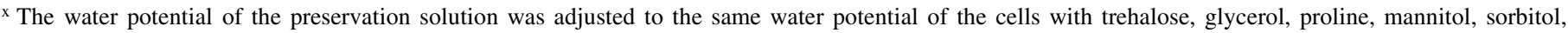
arabitol, glycine, and erythritol. Values are averages of four determinations and the values in brackets show standard errors. Statistical results of least significant difference for viability are shown: a, b, c, and d are separation means for preservation medium and v, w, $\mathrm{x}$, $\mathrm{y}$, and $\mathrm{z}$ for growth medium. Means followed by the same letter are not significantly different.

y Viability mean of preservation media for each growth medium.

z Viability mean of growth medium for each preservation medium. 
expansum inoculated onto apples. Isotonic trehalose liquid formulations were also tested after 7 months of storage. $C$. sake cell density was adjusted with $\mathrm{PB}$ to $10^{7} \mathrm{CFU} \mathrm{ml}{ }^{-1}$. The efficacy was compared with fresh cells grown in the same medium. The isotonic solutions without cells were also tested in order to check that they do not have any effect on efficacy. Fresh cells were obtained following growth in 100-ml conical flasks containing $50 \mathrm{ml}$ of the same medium as formulated cells. After 48-h incubation at $25^{\circ} \mathrm{C}$, the cells were centrifuged at $8,300 \times g$ for $10 \mathrm{~min}$ and resuspended in $50 \mathrm{ml}$ of $\mathrm{PB}$. The cell density was adjusted to $10^{7} \mathrm{CFU} \mathrm{ml} \mathrm{m}^{-1}$ with PB.

'Golden Delicious' apples were wounded with a nail, making an injury of $2 \mathrm{~mm}$ in diameter and $2 \mathrm{~mm}$ deep at the stem (top) and another at the calyx (bottom). Twenty-five microliters of the cell suspension of $C$. sake from each liquid formulation were applied to the wounds. The fruits were allowed to dry at room temperature for approximately $2 \mathrm{~h}$, and the wounds were inoculated with $20 \mu \mathrm{l}$ of an aqueous suspension of $P$. expansum $\left(10^{4}\right.$ conidia $\left.\mathrm{ml}^{-1}\right)$ prepared from 10-day-old cultures incubated on PDA at $25^{\circ} \mathrm{C}$. Each treatment was replicated three times with five apples per replicate and the experiment was conducted two times. The treated apples were incubated at $20^{\circ} \mathrm{C}$ and $85 \%$ relative
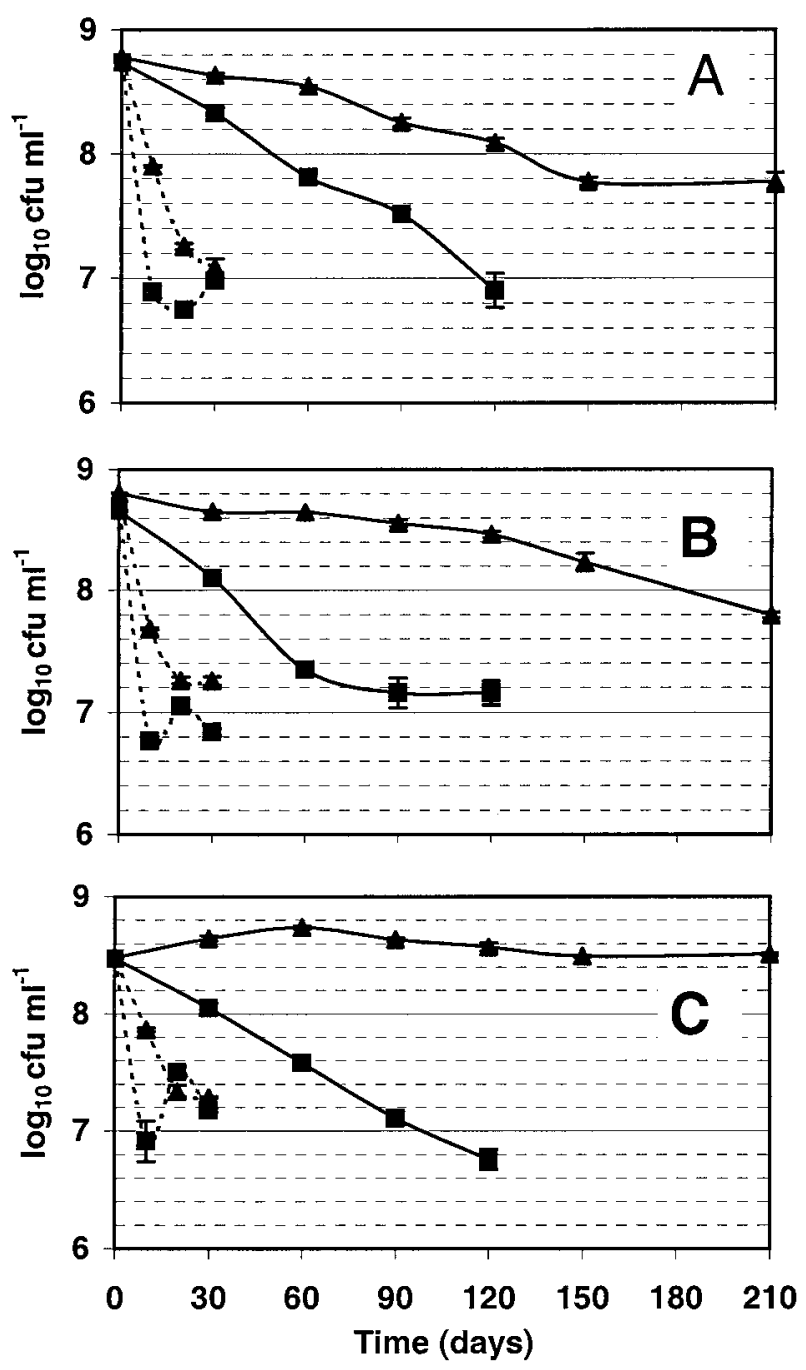

Fig. 1. Viable counts of Candida sake cells preserved in water ( $\mathbf{\square})$ or in the isotonic trehalose solution $(\boldsymbol{\Delta})$ at $4^{\circ} \mathrm{C}(-)$ or at $25^{\circ} \mathrm{C}(----)$. Cells grown in $\mathbf{A}$, unmodified molasses medium, $\mathbf{B}$, in medium modified to 0.98 water activity $\left(\mathrm{a}_{\mathrm{w}}\right)$ with the addition of glycerol, and $\mathbf{C}$, in molasses medium modified to $0.98 \mathrm{a}_{\mathrm{w}}$ with the addition of sorbitol. Verticals bars indicate standard error of means. When they are not visible, they are smaller than symbol size. humidity for 7 days, after which the percentage of infected wounds (incidence) and the lesion diameters (severity) were determined.

Efficacy of liquid formulations of $C$. sake prepared with different trehalose concentrations was also tested after 4 months of storage at $4^{\circ} \mathrm{C}$.

Statistical analysis of results. Data presented are for one representative trial and values represent the mean of at least four replications. The general linear model (GLM) procedure of SAS software (version 6.12 for PC, SAS Institute, Cary, NC) was performed on the percentage of viable cells. To improve the homogeneity of variances, the percentages of viability were transformed to their square root. The effect of growth and preservation media and their interactions were studied as variables. Viability of $C$. sake cells stored at $4^{\circ} \mathrm{C}$ in different trehalose solutions was also studied using the GLM procedure. The effect of growth medium, trehalose concentration, and their interaction was studied. When the analyses were statistically significant $(P<0.05)$, the least significant difference test (LSD) was used for means separation.

The incidence of blue mold data was transformed with the arcsine of the square root of the proportion of infected fruits. When the analysis was statistically significant $(P<0.05)$ the LSD was used for means separation. Severity data were analyzed without data transformation.

\section{RESULTS}

Viability of $C$. sake in isotonic liquid formulations after 10 days of storage at $25^{\circ} \mathrm{C}$. The viability of $C$. sake cells decreased rapidly after 10 days of storage at $25^{\circ} \mathrm{C}$. Isotonic solutions of trehalose were the best of those tested, with viabilities of 25 , 21 , and $30 \%$ when the cells had been grown in the unmodified, glycerol-, and sorbitol-modified molasses media, respectively (Table 2). Irrespective of growth medium, viability of cells preserved with isotonic solutions of sorbitol, arabitol, glycine, and erythritol were $<9 \%$ after 10 days of storage at $25^{\circ} \mathrm{C}$.

There were significant differences in $C$. sake viability depending on the growth and preservation media tested $(P=0.0001$ for both variables). However, there was no interaction between growth and preservation media $(P=0.1023)$. Viabilities of $C$. sake cells grown in the unmodified- $\mathrm{a}_{\mathrm{w}}$ molasses medium followed by the medium modified with glycerol, sorbitol, and proline were higher than those of cells grown in the glucose- and NaCl-modified media. Isotonic solutions of trehalose, glycerol, and proline had the highest protective effect among those tested. Consequently, the unmodified molasses medium and those modified to $0.98 \mathrm{a}_{\mathrm{w}}$ with glycerol or sorbitol were selected as growth media and isotonic solutions of trehalose, glycerol, and proline as preservation media to carry out experiments of long-term storage.

Viability of $C$. sake after storage at 25 and $4^{\circ} \mathrm{C}$. The viability of cells preserved in $\mathrm{PB}$ or in the isotonic solutions of glycerol or proline was similar to that obtained with water. Therefore, only results of water and trehalose are shown (Fig. 1). More cells remained viable at $4^{\circ} \mathrm{C}$ than at $25^{\circ} \mathrm{C}$. The number of viable cells decreased rapidly during the first 10 days of storage at $25^{\circ} \mathrm{C}$, and cells grown in sorbitol-modified medium and preserved with the isotonic trehalose solution obtained the highest viability after 10 days of storage $(25 \%)$. The viability of all treatments after 30 days of storage was $<7 \%$.

After 4 months of storage at $4^{\circ} \mathrm{C}$ and regardless of the growth media used, viability of cells preserved with the isotonic trehalose solution was $>21 \%$, whereas cells preserved with water showed viabilities of $<2 \%$. Consequently, only viability of cells preserved with isotonic trehalose solution was evaluated until 7 months of storage.

Viability of $C$. sake cells grown in the unmodified molasses medium (Fig. 1A) and preserved with the isotonic trehalose solution at $4{ }^{\circ} \mathrm{C}$ decreased progressively and was $72,59,30,21$, and $9 \%$ 
after 30, 60, 90, 120, and 210 days of storage, respectively. Similarly, the number of viable cells grown in the glycerol-modified molasses medium and preserved with the isotonic trehalose solution was $70,70,56,46$, and $10 \%$ after $30,60,90,120$, and 210 days of storage at $4^{\circ} \mathrm{C}$ (Fig. 1B).

In contrast, the number of $C$. sake cells grown in the sorbitolmodified medium and stored at $4{ }^{\circ} \mathrm{C}$ with the isotonic trehalose solution (Fig. 1C) remained stable at about $100 \%$ during the 210 days of storage.

Viability of $\boldsymbol{C}$. sake in trehalose solutions. Generally, for each growth medium, viability of $C$. sake cells was significantly higher when cells were preserved in the trehalose isotonic solution than when cells were maintained in the other trehalose solutions (Table 3).

Viability of cells preserved in water decreased greatly $(<3 \%)$ after 30 days of storage at $4{ }^{\circ} \mathrm{C}$. Generally, at concentrations below the isotonic one, increased concentration of trehalose in the preservation medium implied an increase of the viability of $C$. sake cells. The best viability result was obtained when cells were grown in the sorbitol-modified medium and preserved with the isotonic trehalose solution, with 110 and $77 \%$ of cells remaining viable after 180 and 210 days of storage at $4^{\circ} \mathrm{C}$, respectively.

Efficacy of liquid isotonic formulations stored at $4^{\circ} \mathrm{C}$ for 4 months. The percentage of untreated apples infected with $P$. expansum was $90 \%$, with a mean lesion diameter of $1.5 \mathrm{~cm}$. In contrast, fresh cells grown in the different media showed decay incidence lower than $10 \%$ (Fig. 2). Isotonic solutions themselves, without $C$. sake cells, did not present any biocontrol effect and, in some cases, they increased both incidence and severity of blue mold.

When cells were grown in the unmodified molasses medium (Fig. 2A), all formulations significantly reduced the incidence of decay compared with untreated apples. Efficacy of cells preserved in water or in isotonic trehalose solution was not significantly different than the one obtained with fresh cells, with percentages of infected wounds lower than 20\%. Cells preserved with PB, isotonic solutions of glycerol, or proline significantly reduced the incidence and severity of blue mold but their efficacy was not as good as fresh cells.

When cells were grown in the glycerol-modified medium (Fig. 2B), isotonic formulations prepared with glycerol and trehalose and water suspensions of $C$. sake had the same incidence of decay as fresh cells $(P<0.05)$, with percentages of infected wounds lower than $40 \%$. On the contrary, proline $C$. sake formulation did not reduce the incidence of infected fruits. The efficacy of the PB suspension of $C$. sake was not tested because it was contaminated.
In sorbitol-modified medium (Fig. 2C), C. sake treatments (except cells preserved with proline) significantly reduced the percentage of infection caused by $P$. expansum (rot incidence of $<23 \%$ and lesion diameter reduction of $>86 \%$ ). Cells preserved with water, $\mathrm{PB}$, or the isotonic glycerol solution performed as well as fresh cells. On the contrary, the percentage of infected fruits treated with cells preserved in isotonic proline suspension was not significantly different from that of untreated fruits.

Efficacy of trehalose isotonic formulations stored at $4^{\circ} \mathrm{C}$ for 7 months. Regardless of the growth medium, isotonic trehalose formulations of $C$. sake stored at $4^{\circ} \mathrm{C}$ for 7 months showed good biocontrol effect when they were tested against $P$. expansum infection of apples (Fig. 3), with incidence of decay lower than $18 \%$. In contrast, decay incidence for untreated fruits was $98 \%$. Isotonic trehalose formulation of cells that grew in the sorbitolmodified medium performed as well as fresh cells in controlling blue mold and only $2 \%$ of inoculated apples rotted.

Efficacy of trehalose liquid formulations. Treatment influenced both incidence and severity of decay caused by $P$. expansum on apples $(P=0.0001)$. However, growth medium and the interaction between treatment and growth medium were not significant ( $P=0.9070$ and 0.9631 , respectively). This allowed analyses of all growth media together (Fig. 4). The different solutions of trehalose did not control P. expansum infection by themselves. On the contrary, formulations of $C$. sake and trehalose stored for 4 months at $4^{\circ} \mathrm{C}$ showed the same reduction in incidence of infection and amount of decay as fresh cells (incidence reduction was 56 to $70 \%$ ).

\section{DISCUSSION}

Preservation medium and storage temperature strongly influenced the viability of $C$. sake in liquid formulations. Storage of liquid formulations at $25^{\circ} \mathrm{C}$ is not recommended because cell viability decreases rapidly in a few days. In contrast, some of the liquid formulations stored at $4^{\circ} \mathrm{C}$ maintained $C$. sake viability for several months and performed as well as fresh cells in controlling blue mold rot on apples.

In the first experiment at $4{ }^{\circ} \mathrm{C}$, it was demonstrated that preserving $C$. sake cells with isotonic solutions that maintain the water equilibrium of the cell with its environment did not work properly for the solutes tested, except for trehalose, because the viability achieved with isotonic solutions of glycerol and proline was, in general, similar to that obtained with water or phosphate buffer. Generally, cells grown in the sorbitol-modified medium showed higher viability than cells grown in the unmodified medium or in that modified with glycerol. The growth medium can

TABLE 3. Percentage of viable cells preserved at $4^{\circ} \mathrm{C}$ in relation to growth medium and trehalose concentration in the preservation solution ${ }^{\mathrm{y}}$

\begin{tabular}{|c|c|c|c|c|c|c|c|c|}
\hline \multirow[b]{2}{*}{ Growth medium } & \multirow{2}{*}{$\begin{array}{c}\text { Trehalose } \\
\text { concentration, } \\
\text { (mole per liter) }\end{array}$} & \multicolumn{7}{|c|}{ Storage time at $4^{\circ} \mathrm{C}$ (days) } \\
\hline & & 30 & 60 & 90 & 120 & 150 & 180 & 210 \\
\hline \multirow[t]{5}{*}{ Unmodified } & 0 & $51 \mathrm{a}$ & $17 \mathrm{c}$ & $7 \mathrm{~d}$ & $3 d$ & ND & ND & ND \\
\hline & 0.03 & $55 \mathrm{a}$ & $39 \mathrm{a}$ & $32 \mathrm{c}$ & $24 \mathrm{c}$ & $18 \mathrm{c}$ & $18 \mathrm{~b}$ & $13 \mathrm{c}$ \\
\hline & $\underline{0.14^{\mathrm{z}}}$ & $54 \mathrm{a}$ & $41 \mathrm{a}$ & $54 \mathrm{a}$ & $43 \mathrm{a}$ & $42 \mathrm{a}$ & $32 \mathrm{a}$ & $28 \mathrm{a}$ \\
\hline & $\overline{0.81}$ & $\overline{32 \mathrm{~b}}$ & $\overline{40 \mathrm{a}}$ & $\overline{38 \mathrm{bc}}$ & $\overline{39} \mathrm{ab}$ & $\overline{37 b}$ & $\overline{35 a}$ & $\overline{29 a}$ \\
\hline & 0.96 & $38 \mathrm{~b}$ & $33 \mathrm{~b}$ & $43 \mathrm{~b}$ & $36 \mathrm{~b}$ & $34 b$ & $34 \mathrm{a}$ & $21 \mathrm{~b}$ \\
\hline \multirow[t]{5}{*}{ Glycerol $0.98 \mathrm{a}_{\mathrm{w}}$} & 0 & $42 \mathrm{c}$ & $5 \mathrm{~b}$ & $1 \mathrm{~d}$ & $1 \mathrm{~b}$ & ND & ND & ND \\
\hline & 0.03 & $68 \mathrm{a}$ & $26 \mathrm{a}$ & $35 \mathrm{c}$ & $29 \mathrm{a}$ & $22 b$ & $14 \mathrm{c}$ & $6 \mathrm{~b}$ \\
\hline & 0.14 & $79 a$ & $36 \mathrm{a}$ & $48 \mathrm{~b}$ & $35 \mathrm{a}$ & $38 \mathrm{a}$ & $32 \mathrm{~b}$ & $20 \mathrm{a}$ \\
\hline & $\underline{0.81^{\mathrm{Z}}}$ & $\underline{65 \mathrm{ab}}$ & $37 \mathrm{a}$ & $\underline{55 \mathrm{ab}}$ & $\underline{33 \mathrm{a}}$ & $47 \mathrm{a}$ & $\underline{45 \mathrm{a}}$ & $\underline{20 \mathrm{a}}$ \\
\hline & $\overline{0.96}$ & $\overline{51 \mathrm{bc}}$ & $\overline{36 a}$ & $\overline{58 \mathrm{a}}$ & $\overline{31 \mathrm{a}}$ & $\overline{40 \mathrm{a}}$ & $\overline{32 b}$ & $\overline{20 a}$ \\
\hline \multirow[t]{5}{*}{ Sorbitol $0.98 \mathrm{a}_{\mathrm{w}}$} & 0 & $23 \mathrm{~b}$ & $1 \mathrm{e}$ & $2 \mathrm{e}$ & $2 \mathrm{~d}$ & ND & ND & ND \\
\hline & 0.03 & $90 \mathrm{a}$ & $45 \mathrm{~d}$ & $36 \mathrm{~d}$ & $16 \mathrm{~d}$ & $10 \mathrm{c}$ & $27 \mathrm{~b}$ & $2 \mathrm{~d}$ \\
\hline & 0.14 & $76 \mathrm{a}$ & $65 \mathrm{c}$ & $60 \mathrm{c}$ & $37 c$ & $38 \mathrm{~b}$ & $40 \mathrm{~b}$ & $9 \mathrm{c}$ \\
\hline & 0.81 & $75 \mathrm{a}$ & $109 \mathrm{~b}$ & $105 \mathrm{~b}$ & $92 \mathrm{~b}$ & $118 \mathrm{a}$ & $111 \mathrm{a}$ & $63 \mathrm{~b}$ \\
\hline & $\underline{0.96}^{\mathrm{z}}$ & $\underline{96 \mathrm{a}}$ & $\underline{125 \mathrm{a}}$ & $\underline{121 \mathrm{a}}$ & $118 \mathrm{a}$ & $\underline{108 \mathrm{a}}$ & $\underline{110 \mathrm{a}}$ & $\underline{77 \mathrm{a}}$ \\
\hline
\end{tabular}

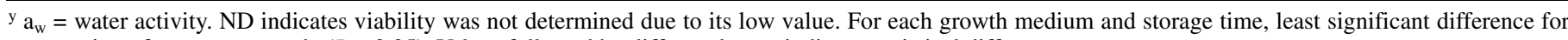
separation of means was made $(P<0.05)$. Values followed by different letters indicate statistical differences among means.

${ }^{\mathrm{z}}$ Underlined values represent the trehalose solution that is isotonic with Candida sake cells. 
influence the pattern of intracellular solutes accumulated in yeast $(23-25,29)$ or conidia (12-14). In some cases, such modifications resulted in improved tolerance to water stress with retained biocontrol activity $(24,25)$. However, no significant changes in the pattern of some polyols were obtained when $C$. sake grew in the sorbitol-modified medium (2). However, Eleutherio et al. (9) found that Saccharomyces uvarum var. carlsbergensis cells were capable of accumulating trehalose when submitted to an osmotic treatment using $20 \%$ solutions of sorbitol endowing them with the capacity of surviving posterior dehydration.

The presence of trehalose in liquid formulations appeared to help preserve cell viability during storage. In the three media used in the experiment at $4^{\circ} \mathrm{C}$, cell viability increased with increased concentrations of trehalose. For this reason, we tested the effect of different concentrations of trehalose in the preservation medium for each growth medium, including the trehalose concentration that was isotonic with cells. Generally for each storage time and growth medium, the increase of trehalose concentration in the preservation medium involved an increase of $C$. sake viability at trehalose concentrations below the isotonic ones. This could suggest that trehalose concentration is not the only factor involved in maintaining $C$. sake viability, but probably it interacts with other factors in the growth medium. It is known that intracellular trehalose exerts a protective effect on yeasts under extreme environmental conditions such as desiccation, freezing, osmotic stress, and heat shock $(5,6,11,15,20,28,30,32)$ and it also provides thermal stability to the cells (4). Gadd et al. (10) pointed out that there is a strong correlation between intracellular trehalose concentra-
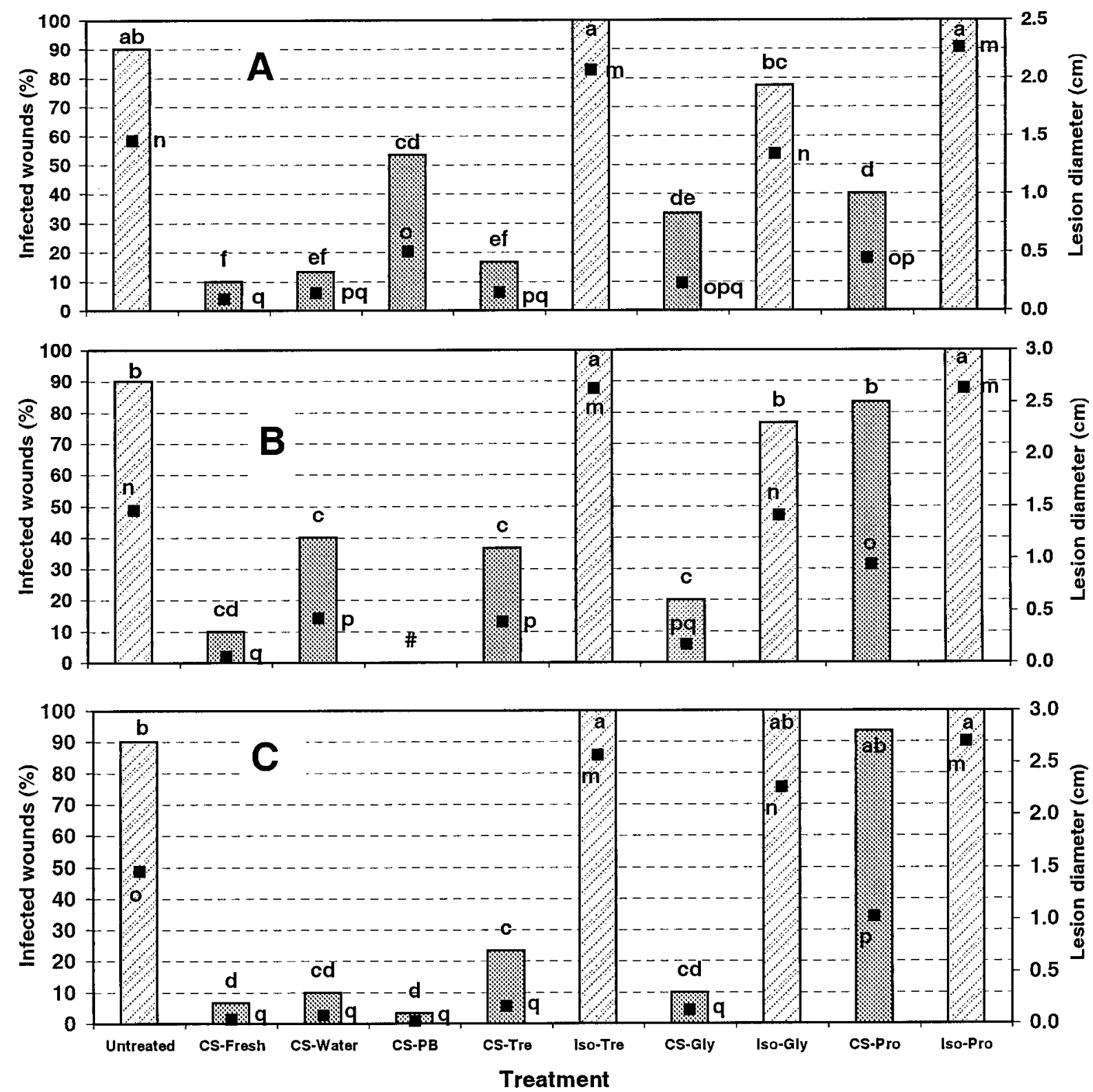

Fig. 2. Efficacy of liquid formulations of Candida sake stored for 4 months at $4^{\circ} \mathrm{C}$ against Penicillium expansum on cv. Golden Delicious apples, compared with no treatment, fresh cells, and the isotonic solution without cells. Fruits were wounded and inoculated with $25 \mu \mathrm{l}$ of fresh or formulated cells of $C$. sake at $10^{7} \mathrm{CFU} \mathrm{ml}{ }^{-1}$ and $20 \mu \mathrm{l}$ of $P$. expansum at $10^{4}$ conidia ml ${ }^{-1}$. Fruits were stored at $20^{\circ} \mathrm{C}$ for 7 days. Cells grown in A, unmodified molasses medium, B, medium modified to 0.98 water activity $\left(\mathrm{a}_{\mathrm{w}}\right)$ with the addition of glycerol, and $\mathbf{C}$, molasses medium modified to $0.98 \mathrm{a}_{\mathrm{w}}$ with the addition of sorbitol. Bars represent the percentage of infected wounds and squares $(\square)$ represent lesion diameter. Different letters indicate significant differences $(P<0.05)$ according to and least significant difference. Treatments: CS-fresh $=$ fresh cells of $C$. sake; $\mathrm{CS}$-water $=C$. sake cells preserved in water; CS-PB $=C$. sake cells preserved in potassium phosphate buffer; CS-Tre $=$ C. sake cells preserved in the isotonic trehalose solution; Iso-Tre $=$ isotonic trehalose solution; CS-Gly $=C$. sake cells preserved in the isotonic glycerol solution; Iso-Gly $=$ isotonic glycerol solution; CS-Pro $=C$. sake cells preserved in the isotonic proline solution; and Iso-Pro $=$ isotonic proline solution. 
tion and the ability of yeast cells to survive long-term frozen storage. In recent years, evidence has been accumulated that trehalose may protect cell viability during drying by replacing the water around polar residues in enzymes and other essential proteins, thus maintaining their integrity in the absence of water $(6,19)$. However, there are no studies on the role played by the external addition of this sugar in protecting yeast cells in liquid formulations. Teixidó et al. (25) found that when $C$. sake was grown in an $\mathrm{a}_{\mathrm{w}}$-modified medium with the addition of trehalose, the intracellular level of trehalose increased. It is possible that $C$. sake could have a trehalose-specific carrier in the cells. Similarly,

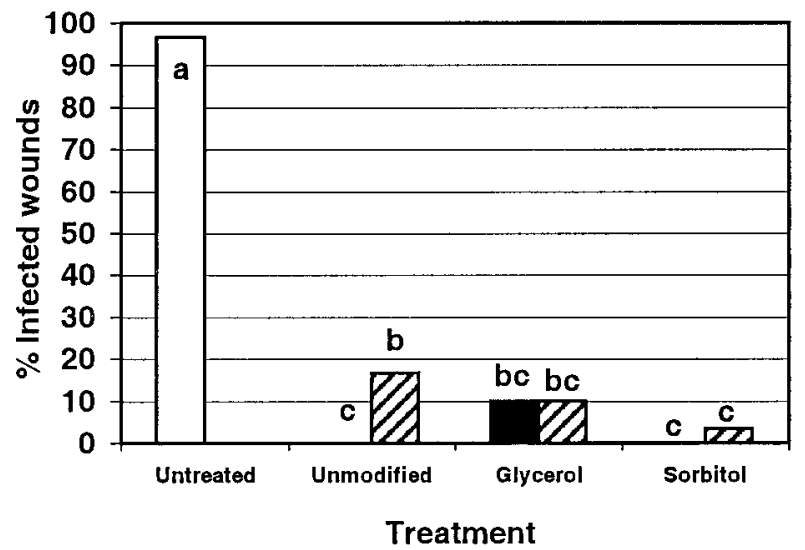

Fig. 3. Comparison of the efficacy of fresh cells and liquid formulations of Candida sake grown in different media and stored for 7 months at $4{ }^{\circ} \mathrm{C}$ against Penicillium expansum infection of cv. Golden Delicious apples. Fruits were wounded and inoculated with $25 \mu \mathrm{l}$ of fresh or formulated cells of C. sake at $10^{7} \mathrm{CFU} \mathrm{m} l^{-1}$ and $20 \mu \mathrm{l}$ of $P$. expansum at $10^{4}$ conidia $\mathrm{ml}^{-1}$. Fruits were stored at $20^{\circ} \mathrm{C}$ for 7 days. Unmodified = cells grown in unmodified molasses medium, Glycerol $=$ cells grown in molasses medium modified to 0.98 water activity $\left(\mathrm{a}_{\mathrm{w}}\right)$ with the addition of glycerol, and Sorbitol $=$ cells grown in molasses medium modified to $0.98 \mathrm{a}_{\mathrm{w}}$ with the addition of sorbitol. $\square=$ untreated apples, $\boldsymbol{\square}=$ fresh cells, and diagonal lines $=$ isotonic trehalose liquid formulations. Different letters indicate significant differences $(P<0.05)$ between treatments according to least significant difference test. in cells of Saccharomyces cerevisiae, external addition of trehalose can replace endogenous synthesis because there appears to be a trehalose-specific carrier (22). Trehalose is accumulated in the cytosol of yeasts (18) and could have a profound influence on the $\mathrm{a}_{\mathrm{w}}$ of the cytosol, slowing down the metabolism and thereby promoting the transition to a resting state of the cells. Thus, trehalose might act as a general inhibitor of metabolic activities to prevent function and preserve the structure of the cells in the stationary state (32). This inhibition of metabolic activities could probably be enhanced at low storage temperatures.

Interestingly, cells grown in the sorbitol-modified medium (198.2 $\mathrm{g}$ of sorbitol liter ${ }^{-1}$ of medium) and preserved with isotonic trehalose solution $(0.96 \mathrm{M})$ remained stable for 7 months at $4^{\circ} \mathrm{C}$. A liquid formulation of chlamydospores of Phytophthora palmivora, DeVine (Abbott Laboratories, North Chicago, IL), is not very stable and has only 6 weeks of shelf life when the product is refrigerated (7). Previous studies (1) demonstrated that only $10 \%$ of freeze-dried $C$. sake cells remained viable after 2 months of storage at refrigeration conditions.

Blue mold of apples was controlled effectively by fresh cells of $C$. sake grown in the different molasses-based media. Some isotonic liquid formulations of $C$. sake stored at $4^{\circ} \mathrm{C}$ for 4 months were as effective as the fresh cells. The efficacy of isotonic trehalose formulations stored at $4^{\circ} \mathrm{C}$ for 7 months was the same as that obtained by fresh cells. Isotonic proline solutions did not control $P$. expansum rot on apples when the cells were grown in glycerol- and sorbitol-modified media. The percentages of infected wounds increased with increased proline concentrations in the preservation medium. It is likely that proline stimulated $P$. expansum growth. Previous studies showed that at concentration of $1 \mathrm{mM}$, L-proline and L-asparagine strongly stimulated conidial germination of $P$. expansum but had little effect on radial growth (17). In laboratory conditions, Janisiewicz and Jeffers (16) found that Bio-Save 11 WP performed as well as fresh cells of the active ingredient, Pseudomonas syringae, in controlling $P$. expansum and Botrytis cinerea on apples. In the same study, Bio-Save $10 \mathrm{WP}$ significantly reduced the incidence of disease, but was less effective than the fresh cells.

It is noteworthy that we have found a liquid formulation of the biocontrol agent $C$. sake with retained viability and efficacy for

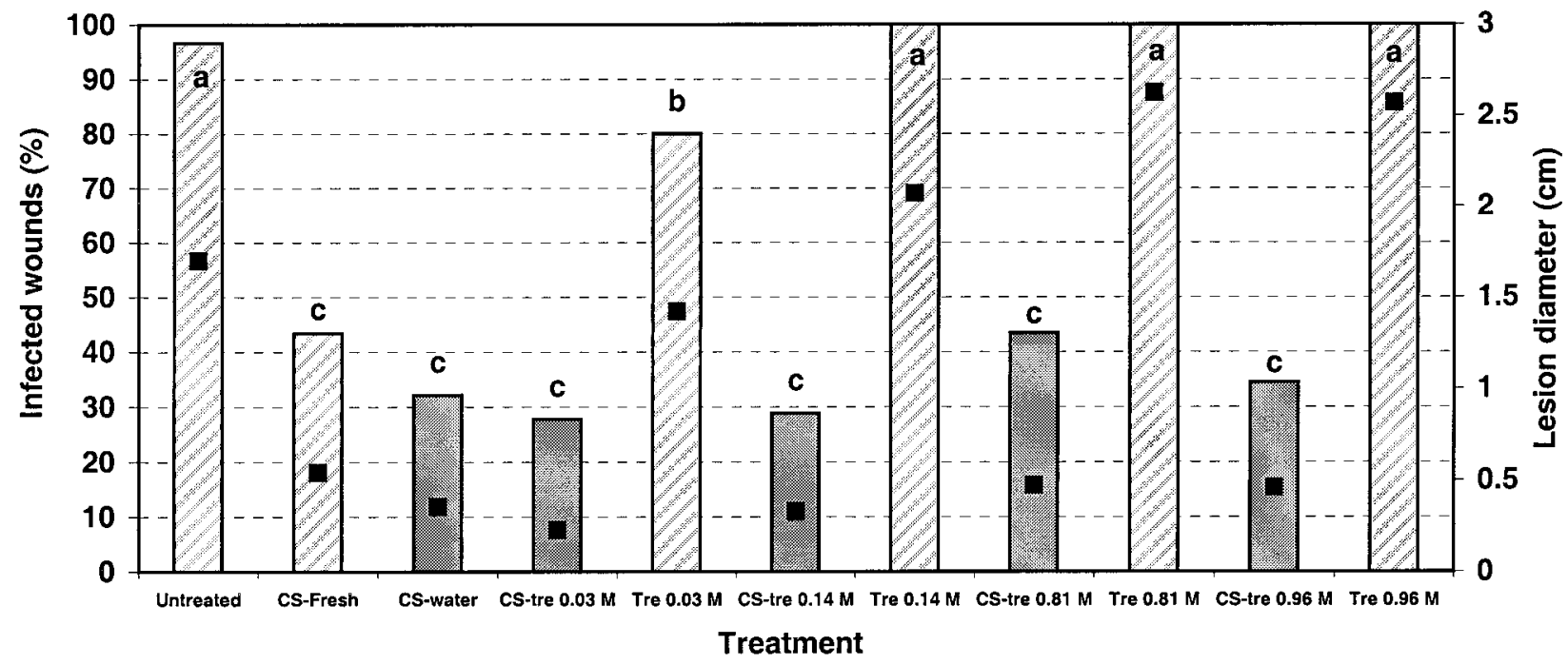

Fig. 4. Efficacy of Candida sake cells formulated with different trehalose concentrations and stored for 4 months at $4^{\circ} \mathrm{C}$ against Penicillium expansum infection of cv. Golden Delicious apples. Fruits were wounded and inoculated with fresh or formulated cells at $10^{7} \mathrm{CFU} \mathrm{ml}^{-1}$ and $P$. expansum at $10^{4} \mathrm{conidia} \mathrm{ml}^{-1}$. Fruits were stored at $20^{\circ} \mathrm{C}$ for 7 days. Bars represent the percentage of infected wounds and squares (ם) represent lesion diameter. Different letters indicate significant differences $(P<0.05)$ according to and least significant difference test. Treatments: CS-fresh $=$ fresh cells of $C$. sake; CS-water $=C$. sake cells preserved in water; CS-tre $0.03 \mathrm{M}=$ C. sake cells preserved in $0.03 \mathrm{M}$ trehalose solution; Tre $0.03 \mathrm{M}=$ trehalose solution $0.03 \mathrm{M}$; CS-tre $0.14 \mathrm{M}=C$. sake cells preserved in $0.14 \mathrm{M}$ trehalose solution; Tre $0.14 \mathrm{M}=$ trehalose solution $0.14 \mathrm{M}$; CS-tre $0.81 \mathrm{M}=C$. sake cells preserved in $0.81 \mathrm{M}$ trehalose solution; Tre $0.81 \mathrm{M}=$ trehalose solution $0.81 \mathrm{M}$; CS-tre $0.96 \mathrm{M}=$ C. sake cells preserved in $0.96 \mathrm{M}$ trehalose solution; and Tre $0.96 \mathrm{M}=$ trehalose solution $0.96 \mathrm{M}$. 
7 months, which will cover the entire pome fruit season, and it is composed of safe substances. However, it should be stored and distributed under refrigerated conditions. The storage and transport of cells at $4^{\circ} \mathrm{C}$ appears not to be an obstacle because other similar products are handled in this way.

\section{ACKNOWLEDGMENTS}

This work was supported by the Spanish Government (MEC, Ministerio de Educación y Cultura), CICYT (Comisión Interministerial de Ciencia y Tecnología, grant ALI99-0652-C02-01), and European Commission QoLPL1999-1065.

\section{LITERATURE CITED}

1. Abadias, M., Teixidó, N., Usall, J., Benabarre, A., and Viñas, I. 2001. Viability, efficacy, and storage stability of freeze-dried biocontrol agent Candida sake using different protective and rehydration media. J. Food Protect. 64:856-861.

2. Abadias, M., Teixidó, N., Usall, J., Viñas, I., and Magan, N. 2000. Solute stresses affect growth patterns, endogenous water potentials and accumulation of sugars and sugar alcohols in cells of the biocontrol yeast Candida sake. J. Appl. Microbiol. 89:1009-1017.

3. Abadias, M., Teixidó, N., Usall, J., Viñas, I., and Magan, N. 2001. Improving water stress tolerance of the biocontrol yeast Candida sake grown in molasses-based media by physiological manipulation. Can. J. Microbiol. 47:123-129.

4. Attfield, P. V., Raman, A., and Northcott, C. 1992. Constructions of Saccharomyces cerevisiae strains that accumulate relatively low concentrations of trehalose, and their application in testing the contribution of the disaccharide to stress tolerance. FEMS Microbiol. Lett. 94:271-276.

5. Cerrutti, P., Segovia de Huergo, M., Galvagno, M., Schebor, C., and Buera, M. P. 2000. Commercial baker's yeast stability as affected by intracellular content of trehalose, dehydration procedure and the physical properties of external matrices. Appl. Microbiol. Biotechnol. 54:575-580.

6. Crowe, J. H., Crowe, L. M., and Chapman, D. 1984. Preservation of membranes in anhydrobiotic organisms: The role of trehalose. Science 223:701-703.

7. Daigle, D. J., and Connick, W. J., Jr. 1990. Formulation and application technology for microbial weed control. Pages 288-304 in: Microbes and Microbial Products as Herbicides. R. E. Hoagland, ed. American Chemical Society, Washington, DC.

8. Droby, S., Cohen, L., Daus, A., Weiss, B., Horev, B., Chalutz, E., Katz, H., Keren-Tzur, M., and Shachnai, A. 1998. Commercial testing of Aspire: A yeast preparation for the biological control of postharvest decay of citrus. Biol. Control 12:97-101.

9. Eleutherio, E. C. A., Maia, F. M., Pereira, M. D., Degré, R., Cameron, D., and Panek, A. D. 1997. Induction of desiccation tolerance by osmotic treatment in Saccharomyces uvarum var. carlsbergensis. Can. J. Microbiol. 43:495-498.

10. Gadd, G. M., Chalmers, K., and Reed, R. H. 1987. The role of trehalose in dehydration resistance of Saccharomyces cerevisiae. FEMS Microbiol. Lett. 48:249-254.

11. Gélinas, P., Fiset, G., LeDuy, A., and Goulet, J. 1989. Effect of growth conditions and trehalose content on cryotolerance of baker's yeast in frozen doughs. Appl. Environ. Microbiol. 55:2453-2459.

12. Hallsworth, J. E., and Magan, N. 1994. Effect of carbohydrate type and concentration on polydydroxy alcohol and trehalose content of conidia of three entomopathogenic fungi. Microbiology 140:2705-2713.

13. Hallsworth, J. E., and Magan, N. 1995. Manipulation of intracellular glycerol and erythritol enhances germination of conidia at low water availability. Microbiology-UK 141:1109-1115.

14. Hallsworth, J. E., and Magan, N. 1996. Culture age, temperature and $\mathrm{pH}$ affect the polyol and trehalose contents of fungal propagules. Appl. Environ. Microbiol. 62:2435-2442.

15. Hirasawa, R., Yokoigawa, K., Isobe, Y., and Kawai, H. 2001. Improving the freeze tolerance of baker's yeast by loading with trehalose. Biosci. Biotechnol. Biochem. 65:522-526.

16. Janisiewicz, W. J., and Jeffers, S. N. 1997. Efficacy of commercial formulation of two biofungicides for control of blue mold and gray mold of apples in cold storage. Crop Prot. 16:629-633.

17. Janisiewicz, W., Usall, J., and Bors, B. 1992. Nutritional enhancement of biocontrol of blue mold on apples. Phytopathology 82:1364-1370.

18. Keller, F., Schellenberg, M., and Wiemken, A. 1982. Localization of trehalase in vacuoles and of trehalose in the cytosol of yeast (Saccharomyces cerevisiae). Arch. Microbiol. 131:298-301.

19. Leslie, S. B., Teter, S. A., Crowe, L. M., and Crowe, J. H. 1994. Trehalose lowers membrane phase transitions in dry yeast cells. Biochim. Biophys. Acta 1192:7-13.

20. Rapoport, A. I., Puzyrevskaya, O. M., and Saubenova, M. G. 1988. Polyols and resistance of yeast to dehydration. Microbiology (NY) 57:269-271.

21. Rhodes, D. J. 1993. Formulation of biological control agents. Pages 411439 in: Exploitation of Microorganisms. D. G. Jones, ed. Chapman \& Hall, London.

22. Salek, A. T., and Arnold, W. M. 1995 Trehalose-stabilisation of osmophilicity and viability of baker's and distiller's yeast: Applications to storage and drying. Chem. Mikrobiol. Technol. Lebensm. 17:14-24.

23. Spencer, J. F. T., and Spencer, D. M. 1978. Production of polyhydroxy alcohols by osmotolerant yeasts. Pages 393-425 in: Economic Microbiology, vol. 2. A. H. Rose, ed. Academic Press, London.

24. Teixidó, N., Viñas, I., Usall, J., and Magan, N. 1998. Control of blue mold of apples by preharvest application of Candida sake grown in media with different water activity. Phytopathology 88:960-964.

25. Teixidó, N., Viñas, I., Usall, J., and Magan, N. 1998. Improving ecological fitness and environmental stress tolerance of the biocontrol yeast Candida sake by manipulation of intracellular sugar alcohol and sugar content. Mycol. Res. 102:1409-1417.

26. Usall, J., Teixidó, N., Fons, E., and Viñas, I. 2000. Biological control of blue mold on apple by a strain of Candida sake under several controlled atmosphere conditions. Int. J. Food Microbiol. 58:83-92.

27. Usall, J., Teixidó, N., Torres, R., Ochoa de Eribe, X., and Viñas, I. 2001. Pilot tests of Candida sake (CPA-1) applications to control postharvest blue mold on apple fruit. Postharvest Biol. Technol. 21:147-156.

28. Van Dijck, P., Colavizza, D., Smet, P., and Thevelein, J. M. 1995. Differential importance of trehalose in stress resistance in fermenting and non-fermenting Saccharomyces cerevisiae cells. Appl. Environ. Microbiol. 61:109-115.

29. Van Eck, J. H., Prior, B. A., and Brandt, E. V. 1989. Accumulation of polyhydroxy alcohols by Hansenula anomala in response to water stress. J. Gen. Microbiol. 135:3505-3513.

30. Van Laere, A. 1989. Trehalose, reserve and/or stress metabolite. FEMS Microbiol. Lett. 63:201-210.

31. Viñas, I., Usall, J., Teixidó, N., and Sanchis, V. 1998. Biological control of major postharvest pathogens on apple with Candida sake. Int. J. Food Microbiol. 40:9-16.

32. Wiemken, A. 1990. Trehalose in yeast, stress protectant rather than reserve carbohydrate. Antonie Leeuwenhoek 58:209-217. 